\title{
Self-efficacy of health professionals in hand hygiene practice: is it possible to measure?
}

\author{
Autoeficácia dos profissionais de saúde para a prática de higiene das mãos: é possível mensurar? \\ Autoeficacia de profesionales de salud em práctica de higiene de las manos: ¿es posible medirla?
}

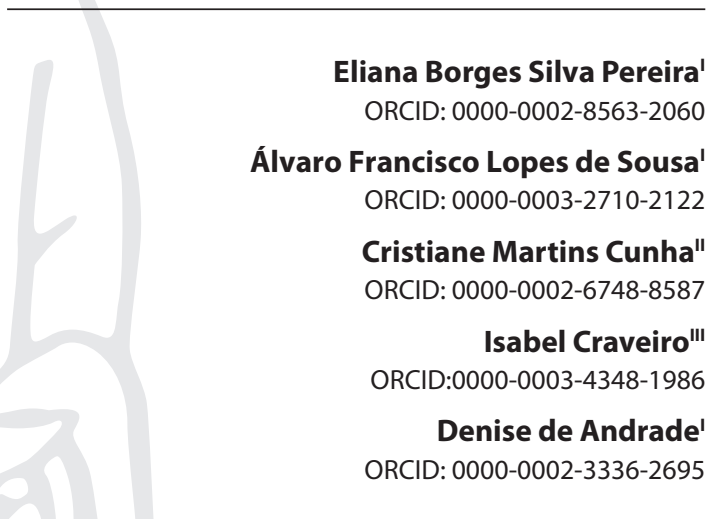

'Universidade de São Paulo. Ribeirão Preto, São Paulo, Brazil.

"Universidade Federal de Uberlândia. Uberlândia,

Minas Gerais, Brazil.

"' Universidade Nova de Lisboa, Instituto de Higiene e Medicina

Tropical. Lisboa, Portugal.

How to cite this article:

Pereira EBS, Sousa AFL, Cunha CM, Craveiro I, Andrade D. Self-efficacy of health professionals in hand hygiene practice: is it possible to measure?

Rev Bras Enferm. 2020;73(Suppl 5):e20190873. doi: http://dx.doi.org/10.1590/0034-7167-2019-0873

\section{Corresponding author: Eliana Borges Silva Pereira \\ E-mail: eborgespereira@yahoo.com.br

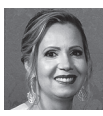

EDITOR IN CHIEF: Dulce Barbosa ASSOCIATE EDITOR: Andrea Bernardes

Submission: 12-12-2019

Approval: 05-10-2020

\begin{abstract}
Objective: To identify in the literature the tools used to measure self-efficacy of health professionals in hand hygiene. Methods: Integrative literature review carried out by consulting the databases PubMed, Scopus, Web of Science, Cumulative Index to Nursing and Allied Health Literature, Europe PubMed Central, and Science Direct using the descriptors Self Efficacy, Hand Hygiene, and Health Personnel. Results: Six articles, all of which with observational design, were selected. It was possible to infer that four studies used validated instruments to measure self-efficacy of health professionals in the conformity with the recommendations for hand hygiene. The other studies used questionnaires that were not validated. Final considerations: Despite the extensive literature on hand hygiene, there is a lack of scientific evidence regarding the use of validated instruments to measure self-efficacy of health professionals in the procedure. The use of properly validated psychometric instruments is useful to guarantee the quality of results in studies.

Descriptors: Self Efficacy; Hand Hygiene; Health Personnel; Infection Control; Behavior.
\end{abstract}

\section{RESUMO}

Objetivo: Identificar, a partir da literatura, as ferramentas utilizadas para mensurar a autoeficácia dos profissionais de saúde na higienização das mãos. Método: Revisão integrativa de literatura, nas bases de dados Pubmed, Scopus, Web of Science, CINAHL, Europe PMC e Science Direct, com os descritores SelfEfficacy, HandHygiene e Health Personnel. Resultados: Selecionaram-se seis artigos, todos do tipo observacional. É possível inferir que quatro estudos utilizaram instrumentos validados para mensurar a autoeficácia dos profissionais de saúde em conformidade com as recomendações para a higiene das mãos. Os outros estudos utilizaram questionários, porém não validados. Considerações finais: Mesmo diante da vasta literatura sobre higiene das mãos, há carência de evidências científicas no que concerne à utilização de instrumentos validados para mensuração da autoeficácia dos profissionais de saúde em relação ao procedimento, pois o uso de instrumentos psicométricos devidamente validados é útil para assegurar a qualidade dos resultados dos estudos.

Descritores: Autoeficácia; Higiene das Mãos; Pessoal de Saúde; Controle de Infecções; Comportamento.

\section{RESUMEN}

Objetivo: Identificar, a partir de la literatura, las herramientas utilizadas para medir la autoeficacia de profesionales de salud en la higienización de las manos. Métodos: Revisión integrativa de literatura, en bases de datos Pubmed, Scopus, Web ofScience, CINAHL, Europe PMC y Science Direct, con los descriptores SelfEfficacy, Hand Hygiene y Health Personnel. Resultados: Fueron seleccionados seis artículos, todos de tipo observacional. Pudo inferirse que cuatro estudios utilizaron instrumentos validados para medir la autoeficacia de los profesionales de salud conforme las recomendaciones para higiene de las manos. Los otros estudios usaron cuestionarios que no estaban validados. Consideraciones finales: Incluso ante la vasta literatura sobre higiene de las manos, se carece de evidencia científica relativa al uso de instrumentos validados para medir la autoeficacia de los profesionales de salud en el procedimiento; el uso de instrumentos psicométricos debidamente validados permite garantizar la calidad de los resultados de los estudios.

Descriptores: Autoeficacia; Higiene de lãs Manos; Personal de Salud; Control de Infecciones; Conducta. 


\section{INTRODUCTION}

Concern with the improvement of healthcare quality is a priority in the mobilization of resources worldwide aiming to guarantee care safety and effectiveness. Among the challenges faced in the health area, measures oriented toward preventing and controlling infections stand out. The consequences of healthcare-associated infections (HAls) can be seen in morbimortality rates and the increase in healthcare-related costs ${ }^{(1-2)}$.

Microbial transmission is often observed when good practices in health are violated ${ }^{(3)}$, which justifies the association of lack of adherence to the recommended precautions, especially low adherence to hand hygiene, with the occurrence of HAls. Health professionals' hands are pointed as one of the main microbial transmission routes ${ }^{(4)}$.

Although careful hand hygiene is the most effective measure to prevent infections ${ }^{(2,5-6)}$, adherence to this practice remains low even in environments where resources and conditions are available $e^{(5-9)}$. Additionally, few interventions are considered long-lasting ${ }^{(7)}$.

One of the main challenges to control the risk of infection implies to invest in changing the behavior of health professionals $^{(3)}$, given that previous studies have shown that promoting hand hygiene requires a multimodal approach that includes personal, cultural, and institutional factors ${ }^{(6,10-11)}$. These findings have suggested that behavioral determinants such as attitude, social influence, and self-efficacy can play a crucial role in adherence to hand hygiene practices ${ }^{(12)}$.

The approach to this challenge in the literature is diverse and sometimes based on professionals' performance, the evaluation of their capacity or motivation, and their engagement to guarantee patient safety. However, there is still a gap regarding self-efficacy in hand hygiene practices.

Having the concept of Albert Bandura ${ }^{(13)}$ as a starting point, self-efficacy refers to the belief a person has in their ability to perform a task, and it depends on their confidence level. The author emphasizes that a high sense of efficacy in a specific domain is not necessarily accompanied by high self-efficacy in other domains. The main sources of self-efficacy (direct experience, vicarious experience, social or verbal persuasion, and physical and emotional states) are considered fundamental elements in the transmission of information that strengthens or weakens people's beliefs in their own capacities ${ }^{(13)}$.

Because self-efficacy is a construct that is not directly observable, it requires a measuring instrument to quantify it. Efficacy beliefs must be measured in terms of particular capacity judgments that may vary between activity domains, under different task demand levels in a certain activity domain, and under situational circumstances ${ }^{(13)}$.

By focusing on the possible relationship between self-efficacy and the performance of health professionals in infection risk situations, the present review had the objective of deepening the knowledge about the influence of cognitive, psychological, and social characteristics on the behavior of adherence to hand hygiene practices.

\section{OBJECTIVE}

To identify in the literature the tools used to measure selfefficacy of health professionals in hand hygiene.

\section{METHODS}

An integrative literature review was carried out. This method allows to incorporate scientific evidence into clinical practice and put together and summarize the results of studies about a delimited subject or question, in a systematic and orderly way, contributing to deepening the knowledge on the examined subject $^{(14)}$.

The following questions were formulated to guide the review: How does the evaluation of self-efficacy of health professionals in hand hygiene happen? Is it possible to measure the self-efficacy of health professionals in their performance of hand hygiene?

The development of the present integrative review was carried out according to six steps: subject choice and definition (question formulation); literature search (sampling); criteria to categorize the studies (data collection); evaluation of the studies included in the results; results discussion; and presentation of the integrative review ${ }^{(14)}$.

A systematic search was carried out in the databases MEDLINE/ PubMed (Medical Literature Analysis and Retrieval System), Scopus, Web of Science (Science Citation Index Expanded), Cumulative Index to Nursing and Allied Health Literature (CINAHL), Europe PubMed Central (Europe PMC), and Science Direct by using the following Medical Subject Headings controlled descriptors: "Self Efficacy", "Hand Hygiene", and "Health Personnel". Combinations of these descriptors were obtained by using the Boolean operator AND.

The inclusion criteria were available papers on the subject in English, Spanish, or Portuguese, with available abstracts, and no time restriction. Specialists' opinions, protocols, editorials, books, theses, dissertations, reviews, and duplicates were excluded.

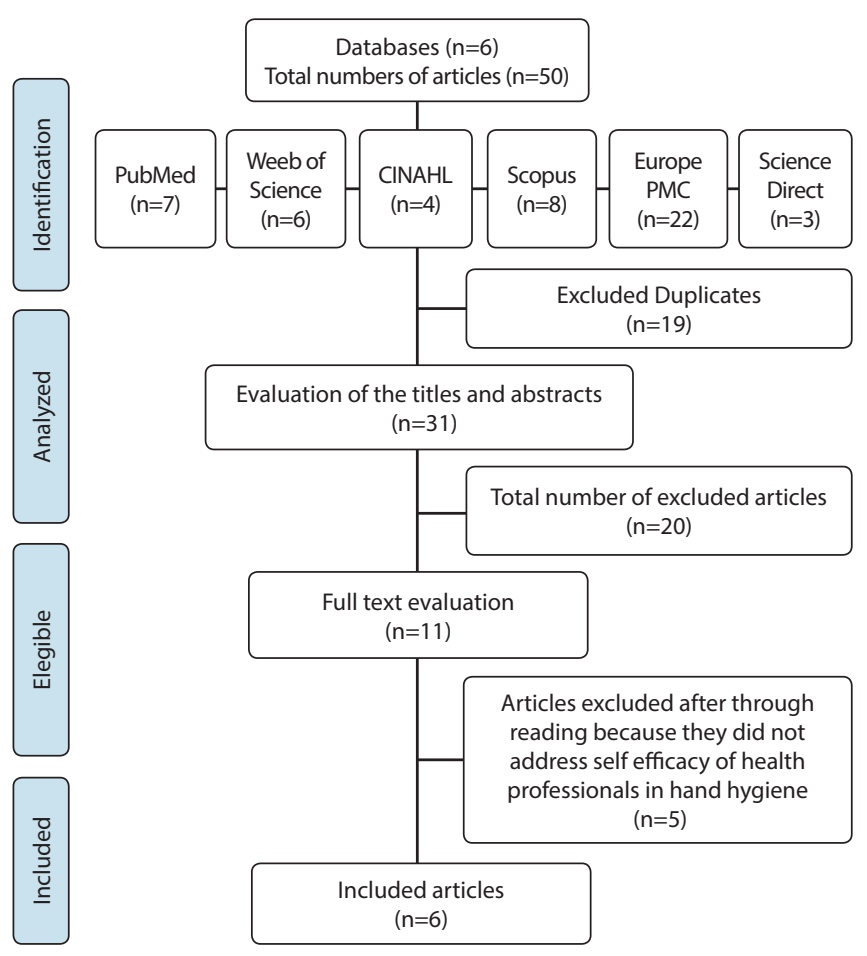

Figure 1 - Flowchart showing the sampling of the integrative review according to the PRISMA Group, 2019 
A bibliographic search was performed in the six databases concomitantly in June 2019 by two researchers with expertise on the examined subject, at the same time and in different places, to prevent bias in the selection of studies to be analyzed.

Meetings were held to discuss the inclusion and exclusion of studies in the review and reach a consensus. A third reviewer was called in when discrepancies could not be sorted out by consensus.

Figure 1 shows a flowchart representing the selection process of the articles related to the research question. The abstracts and full papers were read for a previous evaluation of the studies. Data analysis and interpretation were performed in an organized way by visualizing the information in a table in the Excel $^{\circledR}$ software containing the following summarization columns: study title, database, journal, publication year, country where the study was carried out, study context/location, objective, methodological design, and results and authors' reflections.

\section{RESULTS}

The bibliographic search in different databases resulted in 50 articles, but 19 were excluded because they were duplicates. Consequently, 31 articles had their titles and abstracts analyzed, from which 11 articles were selected for full text reading. Evaluation of the full texts of these publications indicated that six articles were related to the subject and, therefore, were included in the present integrative review.

Chart 1 shows a synthesis of the publications that addressed measurement of self-efficacy of health professionals in their performance of hand hygiene by title, year/journal, objective, study design/method, and main results.

Analysis of the selected studies allowed to infer that four used validated instruments to measure self-efficacy of health professionals in conformity with hand hygiene recommendations ${ }^{(15-18)}$.
In the other two studies, nonvalidated questionnaires were applied, and cognitive factors, knowledge, and perceptions of health professionals were addressed ${ }^{(18-20)}$.

Sax et al. ${ }^{(15)}$ used an anonymous and self-administered questionnaire, designed according to the guidelines of social cognitive theories applied to health-related behaviors, especially the Theory of Planned Behavior. This study evaluated cognitive factors associated with the beliefs of health professionals about the frequency, severity, and impact of HAls, as well as the beliefs of these professionals about their perceived self-efficacy in hand hygiene, perceived social pressure, and perceived self-efficacy. Self-efficacy was higher in nurses, followed by nursing aides and physicians, and it was justified by the belief and perception that hand hygiene required little effort.

The study by Lewis and Thompson ${ }^{(16)}$ used the instrument Health Belief Model, which suggests that people's beliefs about health problems, perceived benefits of action, and barriers to action and self-efficacy explain the engagement (or the lack of it) in behaviors that promote health. Willingness and self-confidence of the professionals to engage in infection control practices stood out in the results of this study. Self-efficacy was high, with the perception of the severity of HAls and preventive behaviors.

In the study by De Wandel et al. ${ }^{(17)}$, self-efficacy was assessed by applying a questionnaire based on the behavioral theoretical model by Albert Bandura to identify the impact of behavioral determinants of self-efficacy of nurses on the conformity with hand hygiene recommendations. The questionnaire about hand hygiene was designed for the study, including a self-reported conformity scale (based on the Centers for Disease Control and Prevention guidelines) and questions about attitudes regarding hand hygiene, social influence, self-efficacy, and knowledge about hand hygiene. The results indicated that the nurses were convinced of the need for hand hygiene but underestimated the consequences of lack of conformity. Self-efficacy in hand hygiene was positively mentioned.

Chart 1 - Publications related to self-efficacy of health professionals in hand hygiene by title, year/journal, objective, study design/method, and main results, 2019

\begin{tabular}{|c|c|c|c|c|}
\hline Title & Year/Journal & Objective & $\begin{array}{l}\text { Study design/ } \\
\text { method }\end{array}$ & Main results \\
\hline $\begin{array}{l}\text { Determinants of good } \\
\text { adherence to hand hygiene } \\
\text { among healthcare workers } \\
\text { who have extensive exposure } \\
\text { to hand hygiene campaigns }{ }^{(15)}\end{array}$ & $\begin{array}{l}\text { 2007/ Infect } \\
\text { Control Hosp } \\
\text { Epidemiol }\end{array}$ & $\begin{array}{l}\text { To quantify the different } \\
\text { behavioral components involved } \\
\text { in the motivation of health } \\
\text { professionals to carry out hand } \\
\text { hygiene }\end{array}$ & Cross-sectional & $\begin{array}{l}\text { Use of a validated questionnaire, } \\
\text { designed according to the } \\
\text { guidelines of social cognitive } \\
\text { theories applied to behaviors } \\
\text { related to health, especially the } \\
\text { Theory of Planned Behavior }\end{array}$ \\
\hline $\begin{array}{l}\text { Health Care Professionals' } \\
\text { Perceptions and Knowledge } \\
\text { of Infection Control } \\
\text { Practices in a Community } \\
\text { Hospital }^{(16)}\end{array}$ & $\begin{array}{l}\text { 2009/The } \\
\text { Health Care } \\
\text { Manager }\end{array}$ & $\begin{array}{l}\text { To evaluate perceptions and } \\
\text { knowledge of health professionals } \\
\text { regarding infection control } \\
\text { practices }\end{array}$ & Exploratory, survey & $\begin{array}{l}\text { Use of the validated instrument } \\
\text { Health Belief Model, a methodology } \\
\text { that allowed to measure constructs of } \\
\text { perceptions and clinical knowledge } \\
\text { about infection control practices }\end{array}$ \\
\hline $\begin{array}{l}\text { Behavioral determinants of } \\
\text { hand hygiene compliance } \\
\text { in intensive care units }{ }^{(17)}\end{array}$ & $\begin{array}{l}\text { 2010/ American } \\
\text { Journal of } \\
\text { Critical Care }\end{array}$ & $\begin{array}{l}\text { To identify and describe predictors } \\
\text { and determinants of noncompliance } \\
\text { with hand hygiene prescriptions in } \\
\text { nurses in an intensive care unit at a } \\
\text { teaching hospital }\end{array}$ & Survey & $\begin{array}{l}\text { Self-efficacy was assessed by } \\
\text { applying a validated questionnaire } \\
\text { based on the behavioral theoretical } \\
\text { model by Albert Bandura }\end{array}$ \\
\hline $\begin{array}{l}\text { Knowledge, perceptions, } \\
\text { and practices of methicillin- } \\
\text { resistant Staphylococcus } \\
\text { aureus transmission } \\
\text { prevention among health } \\
\text { care workers in acute-care } \\
\text { settings }{ }^{(18)}\end{array}$ & $\begin{array}{l}\text { 2014/ American } \\
\text { Journal of } \\
\text { Infection } \\
\text { Control }\end{array}$ & $\begin{array}{l}\text { To evaluate knowledge, } \\
\text { perceptions, and practices related } \\
\text { to hand hygiene and the risk of } \\
\text { contamination by methicillin- } \\
\text { resistant Staphylococcus aureus in } \\
\text { health professionals (physicians, } \\
\text { nurses, and others) }\end{array}$ & $\begin{array}{l}\text { Cross-sectional study } \\
\text { carried out with } \\
\text { professionals at a } \\
\text { hospital in the USA }\end{array}$ & $\begin{array}{l}\text { Use of an instrument with self- } \\
\text { reported measures of the knowledge } \\
\text { of health professionals, as well as their } \\
\text { attitudes, perceptions, practices, and } \\
\text { behaviors about methicillin-resistant } \\
\text { Staphylococcus aureus. The instrument } \\
\text { was validated in the study. }\end{array}$ \\
\hline
\end{tabular}




\begin{tabular}{|c|c|c|c|c|}
\hline Title & Year/Journal & Objective & $\begin{array}{l}\text { Study design/ } \\
\text { method }\end{array}$ & Main results \\
\hline $\begin{array}{l}\text { Intensive care physicians' } \\
\text { and nurses' perception that } \\
\text { hand hygiene prevents } \\
\text { pathogen transmission: } \\
\text { belief strength and } \\
\text { associations with other } \\
\text { cognitive factors }^{(19)}\end{array}$ & $\begin{array}{l}\text { 2015/ Journal } \\
\text { of Health } \\
\text { Psychology }\end{array}$ & $\begin{array}{l}\text { To compare the perception of } \\
\text { physicians and nurses regarding } \\
\text { the belief that hands participate } \\
\text { in microbial transmission and } \\
\text { that hygiene reduces the risk of } \\
\text { transmission. A second objective was } \\
\text { to test associations of this belief with } \\
\text { other sociocognitive determinants }\end{array}$ & $\begin{array}{l}\text { Cross-sectional, survey } \\
\text { study that compared } \\
\text { the perception of } \\
\text { physicians and nurses } \\
\text { in an intensive care } \\
\text { unit at a German } \\
\text { teaching medical } \\
\text { center }\end{array}$ & $\begin{array}{l}\text { The study was based on a } \\
\text { questionnaire tested by the Leibniz } \\
\text { Institute for the Social Sciences, } \\
\text { with items that followed health } \\
\text { psychology and demography } \\
\text { recommendations }\end{array}$ \\
\hline $\begin{array}{l}\text { Assessing Healthcare } \\
\text { Associated Infections and } \\
\text { Hand Hygiene Perceptions } \\
\text { amongst Healthcare } \\
\text { Professionals } \\
(20)\end{array}$ & $\begin{array}{c}2015 / \\
\text { International } \\
\text { Journal of } \\
\text { Caring Sciences }\end{array}$ & $\begin{array}{l}\text { To evaluate the perception of } \\
\text { health professionals (physicians } \\
\text { and nurses) at a hospital in Saudi } \\
\text { Arabia regarding hand hygiene }\end{array}$ & $\begin{array}{l}\text { Descriptive study, } \\
\text { with a World Health } \\
\text { Organization } \\
\text { standardized } \\
\text { questionnaire }\end{array}$ & $\begin{array}{l}\text { Use of the questionnaire } \\
\text { "Perception Survey for Health-care } \\
\text { Workers", standardized by the World } \\
\text { Health Organization }\end{array}$ \\
\hline
\end{tabular}

Seibert et al. ${ }^{(18)}$ used a questionnaire with a five-point Likert scale ranging from 'I strongly disagree' to'I strongly agree' to evaluate knowledge and perception regarding the risk of transmission of methicillin-resistant Staphylococcus aureus by the hands. In the results, the high level of self-efficacy in hand hygiene demonstrated knowledge, perceptions, and preventive practices related to the transmission of methicillin-resistant Staphylococcus aureus in the healthcare environment. However, the authors did not make an instrument to measure self-efficacy in hand hygiene available.

Lutze et al. ${ }^{(19)}$ used items in accordance with health psychology and demography recommendations, cognitively tested by the Leibniz Institute for the Social Sciences, to assess the belief that hand hygiene prevents microbial transmission. The results pointed out that behavioral intention was the factor with the highest average in the sample with nurses and physicians, and $75 \%$ or more of the interviewees reported higher levels of motivation. Nurses and physicians showed a high self-efficacy average value, associated with a strong preventive belief about microbial transmission. Hand hygiene interventions oriented toward risk reduction beliefs may promote high levels of motivation, but not action control.

The study carried out by Tan and Olivo ${ }^{(20)}$ used the questionnaire "Perception Survey for Health-care Workers", standardized by the World Health Organization, to evaluate the preventive belief of physicians and nurses about microbial transmission. The high self-efficacy in the promotion of hand hygiene practices was associated with organizational factors, including the engagement of the staff and the commitment of department heads and leaders. However, the authors concluded that self-reported evaluation of knowledge is not enough to determine whether there is conformity with hand hygiene practices.

Generally, the articles showed that self-efficacy is important, but health professionals ignore its concept.

\section{DISCUSSION}

The behavioral determinant of self-efficacy can play a crucial role in adherence to hand hygiene, that is, adherence is boosted by the perception of high self-efficacy. The study by Sax et al.(15) identified high self-efficacy levels in nurses, whereas other professionals showed lower self-efficacy levels. According to the authors, adherence to hand hygiene was promoted by the professionals' perception of high self-efficacy, rather than their reasoning about the impact of the procedure on patient safety.
It is possible to consider that health professionals may show different self-efficacy levels according to their own judgement on their capacities. It is important to take into account that adherence of health professionals to hand hygiene practices can be extremely low, even when high-quality infrastructure and resources are available.

According to Albert Bandura ${ }^{(13,21)}$, self-efficacy requires not only skills, but also individual and institutional efforts to expand the capacity to carry out a certain conduct, which is an important mediator between knowledge and behavior. Therefore, the feeling of self-efficacy is a prerequisite to change a behavior. Self-efficacy refers to the beliefs that a person has about their value and potentialities. The author believes that a person can make progress in "positive behavior"just like a low self-efficacy level can lead to a delay to adhere to the recommendations and difficulties to comply with them. The concept also refers to self-esteem, to believing in one's own abilities. It is not about having certain skills, but believing that they exist or that it is possible to develop them by means of personal effort, that is, it is a process that involves result expectation ${ }^{(13,21)}$.

In the process of producing these judgments, people must consider several factors that will contribute or not to the shaping of their beliefs, which can be related to specific domains, with the possibility of the existence of high self-efficacy in certain domains and low self-efficacy in others. People with different beliefs can obtain success or failure as a function of these differences in their beliefs ${ }^{(22)}$.

Several researchers have shown that the belief that hand hygiene requires relatively little effort is one of the components of adherence and self-efficacy ${ }^{(2,7,15,23)}$.

Erasmus et al. ${ }^{(23)}$ mentioned that nurses and medical students reported the presence of negative models, that is, they cited the influence of experienced nurses or physicians who did not show conformity with hand hygiene guidelines as a reason for their own noncompliance. The medical students explicitly mentioned that they are incapable of complying with the measures if the rest of the team does not.

Another aspect refers to the fact that the motivation of health professionals seems to have a stronger relationship with normative beliefs (that is, perceived social pressure) and control beliefs (perceived ease to carry out the task) than with beliefs about infections and their prevention ${ }^{(15)}$.

The present study reinforces the existence of a gap of knowledge about the measurement of self-efficacy levels of health professionals in hand hygiene and infection prevention and control practices. In 
general, the studies that address this subject are observational and expose the local situation by applying self-administered questionnaires, with limited investments in the validation of measurement instruments. The need to carry out future studies supported by the design and validation of instruments to measure self-efficacy in different populations of health professionals is notorious.

By developing these studies, it will be possible to establish relationships with cognitive, behavioral, cultural, and institutional characteristics and test them by using previously formulated hypotheses. However, the difficulty of measuring constructs in health, including self-efficacy of health professionals in hand hygiene, is known. It is important to mention that the subject explored in the present study is incipient, especially in the Brazilian context.

The authors stress the importance of developing further studies oriented toward analyzing nursing teams, because they account for the largest contingent of professionals that make up a health staff. As the nursing team is made up of professionals who provide patients with direct care the most, it is involved in the actions to improve care quality and patient safety and, certainly, leads the interventions related to hand hygiene.

As much as hand hygiene practice is simple, the challenge is in the complexity involved in this procedure, because using specific multimodal strategies is not enough to increase adherence. The strategies must be part of the health professionals' routine, and be constantly monitored and evaluated. Additionally, it is important to point out that health institutions face challenges regarding the availability of resources, sizing, and staff.

\section{Study limitations}

The present study has limitations caused by the adopted method. Because it is an integrative review, it only provides an overview of the current state of the art and does not allow to assess educational interventions to promote self-efficacy of health professionals in hand hygiene and the impact of these actions on infection control.

\section{Contributions to the area}

Knowing the self-efficacy of health care professionals in hand hygiene is extremely important, because it can be applied as a health management tool and be useful in the diagnosis of the weaknesses related to knowledge, abilities, and engagement with the execution of good hand hygiene practices and the management of infection control.

\section{FINAL CONSIDERATIONS}

The present study allows to infer about the lack of integration of the theoretical principles of self-efficacy, given that the studies do not include all the individual, collective, and institutional characteristics necessary to adopt and keep the adequate behavior in the same instrument.

The results lead to the conclusion that, even with the extensive literature on hand hygiene, there is a lack of scientific evidence regarding the use of validated instruments to measure the self-efficacy of health professionals in the procedures. The use of properly validated psychometric instruments is useful for guaranteeing the quality of study results.

\section{FUNDING}

The present study was carried out with the support of the Brazilian Coordination for the Improvement of Higher Education Personnel (CAPES - PROEX).

\section{REFERENCES}

1. Boscart VM, Fernie GR, Lee JH, Jaglal SB. Using psychological theory to inform methods to optimize the implementation of a hand hygiene intervention. Implement Sci. 2012;7:77. doi: 10.1186/1748-5908-7-77

2. Graveto JMGN, Rebola R, Fernandes E, Costa PS. Hand hygiene: nurses' adherence after training. Rev Bras Enferm. 2018;71(3):1189-93. doi: 10.1590/0034-7167-2017-0239

3. Giroti ALB, Ferreira AM, Rigotti MA, Sousa AF, Frota OP, Andrade D. Hospital infection control programs: assessment of process and structure indicators. Rev Esc Enferm USP. 2018;52:e03364. doi: 10.1590/s1980-220×2017039903364

4. Allegranzi B, Pittet D. Role of hand hygiene in healthcare-associated infection prevention. J Hosp Infect. 2009;73(4):305-15. doi: 10.1016/j. jhin.2009.04.019

5. Chamchod F, Palittapongarnpim P. Effects of the proportion of high-risk patients and control strategies on the prevalence of methicillinresistant Staphylococcus aureus in an intensive care unit. BMC Infect Dis. 2019;19(1):1026. doi: 10.1186/s12879-019-4632-9

6. Ribeiro IP, Melo JPA, Rocha FCV, Cardoso SB, Carvalho HEF. Adhesion to hand hygiene by the nursing team. Rev Pre Infec e Saúde. 2019;5:8822. doi: 10.26694/repis.v5i0.8822

7. Pittet D. Improving compliance with hand hygiene in hospitals. Infect Control Hosp Epidemiol. 2000;21:381-6. doi: 10.1086/501777

8. Furlan MCR, Ferreira AM, Silva Barcelos L, Rigotti MA, Sousa AFL, Santos Junior AG, et al. Evaluation of disinfection of surfaces at an outpatient unit before and after an intervention program. BMC Infect Dis. 2019;19(1):355. doi: 10.1186/s12879-019-3977-4

9. Silva DS, Dourado AAG, Cerqueira CRE, Romero FH, Amaral NA, Pearce PF, et al. Hand hygiene adherence according to World Health Organization Recommendations in a Neonatal Intensive Care Unit. Rev Bras Saúde Matern Infant. 2017;17(3):551-9. doi: 10.1590/1806-93042017000300008

10. World Health Organization-WHO. Guide to Implementation: a guide to the implementation of the WHO multimodal hand hygiene improvement strategy [Internet]. Geneva, Switzerland: World Health Organization/Patient Safety, A World Alliance for Safer Health Care; 2009[cited 2019 Jun 12]. Available from: https://apps.who.int/iris/handle/10665/70030 
11. Pereira EBS, Jorge MT, Oliveira EJ, Ribeiro Júnior AL, Santos LRL, Mendes-Rodrigues C. Evaluation of the multimodal strategy for improvement of hand hygiene as proposed by the World Health Organization. J Nurs Care Quality. 2017;32(2):E11-E19. doi: 10.1097/ NCQ.0000000000000197

12. Amer HA, Bahar AF, Algamal MN, Alzoman HA, Metwally AM. Behavioral determinants of hand hygiene compliance among physicians in Riyadh region in Saudi Arabia. J Arab Soc Med Res [internet]. 2017 [cited 2019 Jun 12];12:99-105. Available from: https://www.ncbi.nlm.nih. gov/pubmed/24562513

13. Bandura A. Self- Efficacy: the exercise of control. New York: Freeman, 1997.

14. Mendes KDS, Silveira RCCP, Galvão CM. Revisão integrativa: método de pesquisa para a incorporação de evidências na saúde e na enfermagem. Texto Contexto Enfermagem. 2008;17(4):758-64. doi: 10.1590/S0104-07072008000400018

15. Sax H, Uckay I, Richet H, Allegranzi B, Pittet D. Determinants of good adherence to hand hygiene among healthcare workers who have extensive exposure to hand hygiene campaigns. Infect Control Hosp Epidemiol. 2007;28:1267-74. doi: 10.1086/521663

16. Lewis KL, Thompson JM. Health care professionals' perceptions and knowledge of infection control practices in a community hospital. Health Care Manag. 2009;28(3):230-9. doi: 10.1097/HCM.0b013e3181b3ea8b

17. Wandel D, Maes L, Labeau S, Vereecken C, Blot S. Behavioral determinants of hand hygiene compliance in intensive care units. Am J Crit Care. 2010;19(3):230-9. doi: 10.4037/ajcc2010892

18. Seibert DJ, Speroni KG, Mi Oh K, DeVoe MC, Jacobsen KH. Knowledge, perceptions, and practices of methicillin-resistant Staphylococcus aureus transmission prevention among health care workers in acute-care settings. Am J Infect Control. 2014;42(3):254-9. doi: 10.1016/j. ajic.2013.09.005

19. Lutze B, Chaberny IF, Graf K, Krauth C, Lange K, Schwadtke L, et al. Intensive care physicians' and nurses' perception that hand hygiene prevents pathogen transmission: belief strength and associations with other cognitive factors. J Health Psychol. 2015;22(1):89-100. doi: $10.1177 / 1359105315595123$

20. Tan AK, Olivo J. Assessing Healthcare Associated Infections and Hand Hygiene Perceptions amongst Healthcare Professionals. Int J Caring Sci [Internet]. 2015[cited 2019 Jun 12];8(1):108-14. Available from: http://www.internationaljournalofcaringsciences.org/docs/13-abstract.pdf

21. Bandura A. Self-efficacy: toward a unifying theory of behavioral change. Psychol Rev. 1977;84(2):191-215. doi: 10.1037//0033-295x.84.2.191

22. Barros M, Batista-dos-Santos AC. Por dentro da autoeficácia: um estudo sobre seus fundamentos teóricos, suas fontes e conceitos correlatos. Rev Espaço Acad [Internet]. 2010 [cited 2019 Jun 12];112. Available from: http://www.periodicos.uem.br/ojs/index.php/EspacoAcademico/ article/view/10818

23. Erasmus V, Brouwer W, van Beeck EF, Oenema A, Daha TJ, Richardus JH, et al. A qualitative exploration of reasons for poor hand hygiene among hospital workers: lack of positive role models and of convincing evidence that hand hygiene prevents cross-infection. Infect Control Hosp Epidemiol. 2009;30:415-9. doi: https://doi.org/10.1086/596773 